\title{
The Strategy of Agriculture Land Management at Gunungsari Area, Kucur Village, Dau, Malang
}

\author{
Yugo Indah Pertiwi ${ }^{1 *}$, Kliwon Hidayat ${ }^{2}$, Yayuk Yuliati ${ }^{2}$ \\ ${ }^{1}$ Postgraduate of Sociology Program, Faculty of Agriculture, Brawijaya University, Veteran St. (65145), \\ Malang, Indonesia \\ ${ }^{2}$ Department of Socio-Economics, Faculty of Agriculture, Brawijaya University, Veteran St. (65145), \\ Malang, Indonesia
}

Received: 11 June 2020; Revised: 13 July 2020; Accepted: 20 September 2020

\begin{abstract}
The purpose of this study is to describe the structure of land ownership and agricultural land management strategies in the Gunungsari region and explore the socio-economic and ecological conditions that drive the selection of existing land management strategies. The case study was chosen as a research design with Gunungsari agricultural land area as the case. Data collection was carried out through in-depth interviews with key informants, semi-structured interviews with sample farmers, field observations and documents. Data were analyzed descriptively qualitatively. The results of the study illustrate that dominant individual agricultural land ownership is fragmented into different plot locations with an area of less than 0.5 hectares. Perennial crop monoculture, annual intercropping, perennial crop intercropping, and mixed gardens are available agricultural land management strategies. Perennial crops as the main crops as well as edge crops are still the dominant choice of farm families, according to the internal uniqueness of each family in their interactions with external factors. This choice has consequences for the current land cover of the Gunungsari region. The actor approach that places social practice as a result of dynamic interactions between the actor's internal conditions and the context of his social-ecological environment is seen as relevant.
\end{abstract}

Keywords: ownership; management; actors; environment

\section{How to Cite:}

Pertiwi, Y. I., Hidayat, K., \& Yuliati, Y. (2020). The Strategy of Agriculture Land Management at Gunungsari Area $\quad$ Kucur. HABITAT, 31(3), 125-135. https://doi.org/10.21776/ub.habitat.2020.031.3.15

\section{Introduction}

Agriculture has many important functions in life. The existence of these functions is largely determined by how society in general and farmers, in particular, manage their agricultural land. Medium and highland areas are generally located in the upstream area. This area is characterized, among other things, by the dominance of dry land with various topographical conditions, namely wavy to hilly. In this area, agricultural land management strategies that support the sustainability of multi-function agriculture are needed. These functions include producing food, providing employment, mitigating floods, controlling soil erosion, maintaining groundwater supply, carbon tethering, air conditioning, and freshening, recycling organic waste, preserving

${ }^{*}$ Correspondence author

E-mail: yugopertiwi@gmail.com biodiversity, preserving socio-cultural values, and rural (rural) attractiveness amenity, a buffer for economic stability during a crisis, and so on. In other words, agriculture has the function of preserving environmental quality, food security, and socio-economic stability (Adimihardja, 2006).

Agricultural multifunction has a nonexcludability characteristic, that is, the services produced can be enjoyed free of charge, not only by the farmers who produce them but also by the wider community. Agricultural multifunction is also non-rivalry, that is, people can enjoy these services without having to compete because these services are public goods (Thieme, 2011).

The results of some various studies show that a dry land with a tree-based agricultural system (mixed garden/agroforestry) and the presence of litter covering the soil surface has a lower level of erosion compare to a land used for seasonal crop farming. Likewise, water buffering capacity (flood mitigation power) is high in a tree- 
based land use (Agus \& Husen, 2005). However, farming communities tend to manage their land with this tree-based farming strategy and they manage their land with seasonal crops is still controversial.

On the one hand, large farmers tend to manage their land with the choice of a mixed garden system, because they have the capital and their daily needs do not depend on the land (Astuti, Dharmawan, Intan, \& Putri, 2008). The results of the study (Suryanata, 1994) showed that the mixed garden systems (fruit trees and seasonal crops) are the choice of broad farmers because they are more profitable than the seasonal crops. The same thing was also stated by (Kartodihardjo, 2014) that farmers are interested in planting timber trees (community forests) because it is more profitable. He further argued that this had happened, because the price of wood was getting better, in line with the increasing demand for wood.

While on the other hand, (Palte, J.G. 1984) reported that dry land farmers in rural Java, tend to manage their land with seasonal crops, especially food crops. Because they are more encouraged to meet the basic needs of their daily life. Moreover, rural communities in Java dryland areas are experiencing high population pressure on land resources. This means that the land controlled by them cannot meet the needs of their family. According to (Manurung 2004), in a society like this, the priority to fulfill their needs is short-term (urgent). Therefore, this is natural because the annual crops are fast producing, so that the seasonal crops are their main choice in managing their land. This condition is mainly found in farmers with narrow land areas or in areas with high population pressure on land (Astuti et al., 2008). Meanwhile, research results (Husen, Watung, \& Agus, n.d., 2004) stated that farmers do not plant certain types of plants (including types of trees), because they do not know the multifunctionality of those plants. Most farmers in developing countries including Indonesia only know 2-3 agricultural functions (Adimihardja, 2006).

In certain dryland rural areas, there is a phenomenon of community members, especially those who belong to the lower middle class looking for work outside agriculture to meet the needs of their families (Schouten, Van der Heide, \& Heijman, 2009). They look for non-agricultural work in the nearest city/suburb by doing circular migration (shuttle migration) or in a big city or outside Java (Sudomo, 2013).
Therefore, they do not have enough time to manage their narrow agricultural land. The solution they took was that the land was planted with some trees such as sengon laut laut or jabon. This plant after planting does not require intensive maintenance and low maintenance costs (Lastiantoro dan Cahyono, 2015). Meanwhile, their daily needs are met from non-agricultural activities. Thus, farmers who have narrow land in rural communities also have the opportunity to manage their land with tree crops (mixed gardens).

This also influenced the formation of a wood-based agroforestry farming system in Gunungsari, which is an agricultural land with hilly land structure. The existence of timber is the main vegetation in the use of agricultural land in Gunungsari, thus forming the land cover in the area. Interestingly, in the midst of many problems with land degradation in privately owned agricultural lands in the medium-highland area, Gunungsari grows into private agricultural land which grows with an agroforestry system dominated by timber which is suitable for a land conservation in the upstream area.

Therefore, what is interesting to be studied further is; how is the structure of agricultural land ownership in the Gunungsari area? Which farmers tend to cultivate their entire land using a mixed garden system, or a combination of mixed gardens and seasonal crops, or all of their land is cultivated by annual crops? What socio-ecological conditions made them choose the land management strategy? It is interesting to note the dynamics of the choice of the land management strategies because they have some consequences on land cover in this area. This is important for the village government, the Brantas River Basin Center (BBDAS), and other relevant agencies for the preservation and sustainability of the agricultural land and springs in the area as well as the development of human ecology and agricultural sociology for sustainable agricultural development.

\section{Research Methods}

This research used a qualitative approach with a case study design. A case is the management of agricultural land in Gunungsari area, Kucur Village, Dau District, Malang Regency. Because the focus of the study is on the contemporary phenomena in the context of reallife and is uniqueness in land management in this village, Robert K Yin (Reese, 2000). The data sources consisted of 3 key informants and 25 
sample farmers who manage the land in Gunungsari area. Key informants were selected purposively (purposive), namely those who have completed and extensive knowledge of the land management in this area so far. In addition, they also have experience in the land management in Gunungsari area. Meanwhile, farmers are selected for the diversity of the agricultural land management

The data collection was carried out through in-depth interviews and semi-structured interviews, field observations, and documents. Indepth interviews were conducted with three key informants, while semi-structured interviews were conducted with 25 sample farmers. In addition, direct observations were made on the diversity of the agricultural land management that was selected and carried out by the farmers in Gunungsari area. Documents regarding ownership of agricultural land in Gunungsari area were obtained from the Kucur village office, namely from the national program committee (prona) land ownership certificates, particularly land ownership in Gunungsari area.

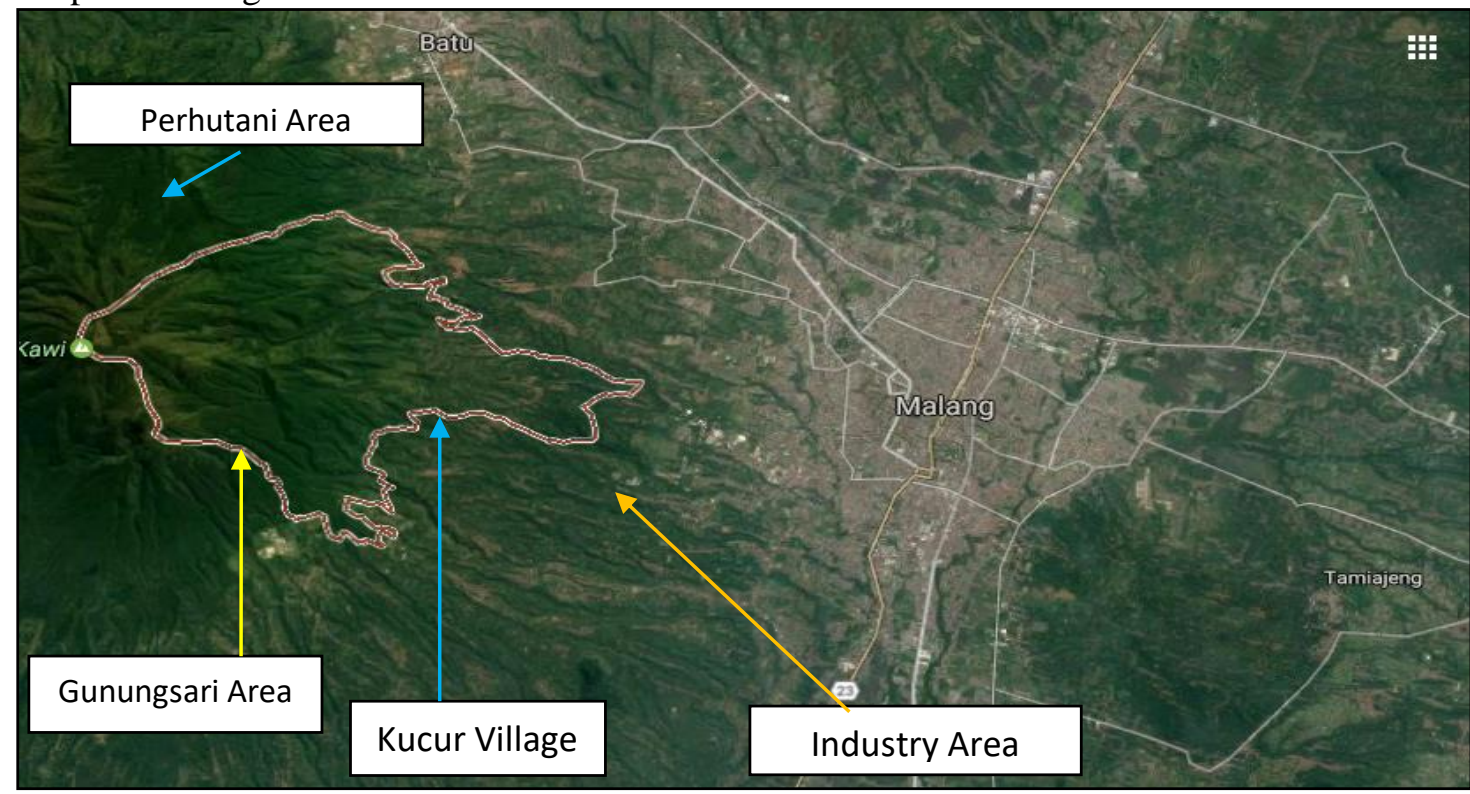

Picture 1. Location Map of Kucur Village and Gunungsari Area and its Surrounding Environment Source: Google map accessed, 15 March 2020

\subsection{Land Tenure Structure and Patterns}

The land area at Gunungsari area in Kucur village area is 152.5 ha. Of the total area, 3.6 hectares are managed by the village government. This land is close to the location of Gunungsari spring. The land managed by the village is then developed into a nature-based village bathing park. The rest is land owned by farmers, most of whom live in the Kelampok hamlet, Kucur village (Picture 2.).
The data were analyzed descriptively by using tables and interactive models in Miles and Hubermas (Ruíz, 2015). The qualitative data collected was carried out by the data condensation process, data presentation, and drawing conclusions.

\section{Results and Discussion}

\subsection{Gunungsari Area Settings}

Gunungsari is administratively located in four village areas, namely, Kucur Village, Kalisongo Village, Pandanlandung Village, and Jedong (Wagir Subdistrict), but most of Gunungsari area is in Kucur Village area. According to Rohim (Kasun Kelampok), 65 percent of the total area of Gunungsari is in the village of Kucur. He further stated that the distribution of land ownership in Gunungsari ranges from $1000 \mathrm{~m} 2-6000 \mathrm{~m} 2$, with an average ownership area of $4000 \mathrm{~m} 2$. The condition of the soil in Gunung Sari is clay. 
However, since the last few years, there have been parts of Gunungsari area, with an area of 10 hectares bought by property companies, namely PT Hattaka Utama and PT. Podojoyo. For the time being, the property company handed over the management of the land to the former landowners.

Based on the data from the National Program (prona) for local land certification, it was recorded that 278 people owned land in Gunungsari area in the Kucur village area (Table 1). From the table data, $95 \%$ of landowners belong to the land area of fewer than 0.500 hectares. The search results show that there are many landowners (children) whose management is still one with the land of their parents. Therefore, based on the reality on the ground.

It is certain that the number of landowners of less than 0.500 hectares will decrease, but will still be the dominant number, while the ownership class of more than 0.500 hectares will increase. Likewise, the total number of landowners in Gunungsari area will be less than 278 people.

Table 1. The Classification of Land Ownership Area at the Gunungsari Area in 2019

\begin{tabular}{|c|c|c|c|c|}
\hline No. & $\begin{array}{c}\text { Land } \\
\text { Area } \\
\text { Classes }\end{array}$ & $\begin{array}{l}\text { Total } \\
\text { Land } \\
\text { (Ha) }\end{array}$ & $\begin{array}{c}\text { Total } \\
\text { (Family) }\end{array}$ & $\begin{array}{c}\text { Percent } \\
\%\end{array}$ \\
\hline & Less than & & & \\
\hline 1 & 0.5 & 41.1 & 265 & 95.3 \\
\hline 2 & $0.5-1.0$ & 57.0 & 9 & 3.2 \\
\hline 3 & $\begin{array}{l}\text { Above } \\
\text { than } 1.0 \\
\text { Village } \\
\text { Land/ }\end{array}$ & 50.8 & 3 & 1.1 \\
\hline 4 & Perhutani & 3.6 & 1 & 0.4 \\
\hline & Total & 152.5 & 278 & 100.0 \\
\hline
\end{tabular}

Source: Kucur Village Prona Program Committee, 2019.

Meanwhile, from the small sample data, the distribution of the land ownership is obtained as presented in table 2 . The determination of sample farmers here is based on the diversity of the agricultural land management systems, not for the representation of land ownership in Gunungsari area. From these data, it can be concluded that the land ownership structure in Gunungsari area is dominant in the land area of fewer than 0.500 hectares. However, from the real conditions in the field, the land area of 0.500-1,000 hectares and more than 1,000 hectares, respectively, is not as small as $3.2 \%$ and $1.1 \%$ as in table 1 above, because the agricultural land in Gunungsari that has been certified on behalf of children his son is still in the same management with his parents.

Table 2. The Structure of Agricultural Land Undertaking according to the Group of Farmer Household Land in the Gunungsari Area in 2019

\begin{tabular}{|c|c|c|c|c|}
\hline No. & $\begin{array}{l}\text { Land } \\
\text { Tenure }\end{array}$ & $\begin{array}{c}\text { Land } \\
\text { Area } \\
\text { Average } \\
\text { (Ha) }\end{array}$ & $\begin{array}{c}\text { Total } \\
\text { Family }\end{array}$ & $\begin{array}{c}\text { Percentage } \\
(\%)\end{array}$ \\
\hline & $\begin{array}{l}\text { Less } \\
\text { than }\end{array}$ & & & \\
\hline 1 & $\begin{array}{c}0.5 \\
0.5-\end{array}$ & 0.23 & 7 & 28 \\
\hline 2 & $\begin{array}{c}1.0 \\
\text { Above } \\
\text { than }\end{array}$ & 0.50 & 12 & 48 \\
\hline 3 & $\begin{array}{c}1.0 \\
\text { Total }\end{array}$ & 2.81 & $\begin{array}{r}6 \\
25\end{array}$ & $\begin{array}{r}24 \\
100\end{array}$ \\
\hline
\end{tabular}

The land owned by Gunungsari farmers appears to be fragmented. Most (64\%) farmers in Gunungsari own more than 1 location, the remaining $36 \%$ of farmers own land in only 1 location, which can be followed in Table 2 below. So even though the average dominance of agricultural land has moderate ownership, the presence of land (64\%) in a regular manner results in a narrow and scattered plot of land.

Table 3. The Composition of Farmers by Number of Agricultural Land Locations in Gunungsari, Kucur Village, 2019

\begin{tabular}{cccc}
\hline No. & $\begin{array}{c}\text { Total } \\
\text { Location }\end{array}$ & $\begin{array}{c}\text { Total } \\
\text { Family }\end{array}$ & $\begin{array}{c}\text { Percentage } \\
(\boldsymbol{\%})\end{array}$ \\
\hline 1 & 1 & 9 & 36 \\
2 & 2 & 7 & 28 \\
3 & 3 & 7 & 28 \\
4 & $\geq 4$ & 2 & 8 \\
\hline & Total & 25 & 100 \\
\hline
\end{tabular}

The number of these locations (table 3) shows the fragmentation that occurs in the farmers' land ownership that $64 \%$ of households own multiple farms. The number of farming locations that are more than one is a challenge for the farmers in managing agriculture. Land owned by the farmers in more than one location has a relationship with the various land management strategies. The strategic options for smallholder land management are described in the following sections. 


\subsection{Agricultural Land Management Strategy (SPL) in Gunungsari Area}

The agricultural land management system in Gunungsari area is an adaptation strategy carried out by the farmers to agricultural land. Basically, the agricultural system that dominates and appears in this area is an agricultural system based on agroforestry, which is a form of agricultural business that combines tree crops, or perennial crops with other seasonal crops that are planted together or alternately. However, the agricultural management in each plot of land depends on the choices made by each farmer's household. The variety of agricultural land management in Gunungsari area will be explained in the following description.

\section{a. Annual Plant Monoculture \\ (MTT/Monokultur Tanaman Tahunan)}

A form of management of agricultural land cultivated with one type of perennial plant/timber. In the research location, the plants cultivated by the farmers were sea senton (Albizzia falcata). This form is mostly cultivated by the farmers in Gunugsari area whose Sengon laut plants are over 3 years old. Before reaching the age of 3 years, the land under the Sengon laut tree stands is planted with cayenne pepper, ginger, or corn. Apart from that, land planted with mahogany was also found, especially on the land managed by the village government.

b. Seasonal Crop Intercropping
(TTS/Tumpangsari Tanaman Semusim)
It is a form of agricultural land management, where the processed land is only planted with various seasonal crops. In the research location, the annual crops cultivated by the farmers are ginger and cayenne pepper, and there is also corn with cayenne pepper. It should be noted that due to the sloping topography of the land, bench terraces are made on this stretch of land, the lip of the terraces is planted with elephant grass (kolonjono) and on the edges of the land are planted with woody plants such as pete, teak, waru, mahogany, sengon laut laut, and glirisidi (Gliricidia maculate).

c. Intercropping of perennial crops (TTT/Tumpangsari Tanaman Tahunan)

Intercropping of annual crops is a system of planting an agricultural land with a variety of annual crops. In the research location, the farmers carried out mahogany, sengon laut laut, and bamboo plants, and there were sengon laut, coffee, durian, cloves, bananas, waru, and other annual woods.

\section{d. Mixed Garden (KC/Kebun Campuran)}

Another form of cultivated agricultural land using an intercropping system between annual and seasonal crops. Annual crops consists of woody plants and fruit trees. In Gunungsari area, this form of management is the intercropping of sengon laut, jabon, mahogany and elephant grass, ginger, lemongrass, or oranges and ginger.

How is the distribution of agricultural land management in Gunungsari area by the farmers can be followed in Table 4 below. Table 4 . explains that in Gunungsari area, there are 4 types of agricultural land management, namely annual crop monocultures (MTT), seasonal crop intercropping (TTS), annual crop intercropping (TTT), mixed gardens (KC); annual plant monocultures (MTS). However, each farmer applies one form/type of land management, and some apply a combination of several forms of agricultural land management. Those who apply one form of land management are up to $60 \%$, while the rest (40\%) apply a combination of 2 to 4 forms of agricultural land management. What socio-economic conditions encourage the farmers to choose the type of agricultural land management, will be described in the following section.

Table 4. Percentage of the Farmers according to the Agricultural Land Management System in Gunungsari Area, Kucur Village, 2019

\begin{tabular}{clcc}
\hline System & $\begin{array}{c}\text { Variety of } \\
\text { Agricultural } \\
\text { Land } \\
\text { Management }\end{array}$ & $\begin{array}{c}\text { Total } \\
\text { (Farmers) }\end{array}$ & $\begin{array}{c}\text { Percentage } \\
(\%)\end{array}$ \\
\hline A & MTT & 6 & 24 \\
B & TTS & 5 & 20 \\
C & TTT & 4 & 16 \\
D & MTT+TTS & 5 & 20 \\
E & KC+TTS & 1 & 4 \\
F & KC+TTT & 2 & 8 \\
G & MTT+MTS+TTS & 1 & 4 \\
& KC+MTT & 1 & \\
H & +TTS+TTT & & 4 \\
\hline & Total & 25 & 100 \\
\hline
\end{tabular}

Notes: Annual plant monoculture (MTT), annual crop intercropping (TTS), annual crop intercropping (TTT). Talun (mixed garden) $(K C)$; Seasonal plant monocultures (MTS); 


\subsection{Socio-Economic Conditions that Encourage the Choice of Land Management Strategies}

As previously described, the status of agricultural land at Gunungsari area is owned by individuals (real land). Therefore, the decision making in the management of agricultural land lies with the farmer family unit. Thus, the farmers and their families are the important actors in the choice of the strategies for managing their cultivated land. The agricultural land management strategy in question is the selection of plant types, the application of cropping systems and patterns, methods of farming, or the choice of strategies for managing arable land as a whole.

Decision making regarding the choice of agricultural land management strategies within the farmer family unit is complex. This means that many factors are taken into consideration by the farmers, both internal conditions and external factors of the family. Internal and external family factors that determine the choice of land management strategies for farmers in Gunungsari area can be followed as follows.

\section{a. Family needs}

One of the main needs of the family is food. For families whose orientation is to meet basic food needs and non-staple food, they will plant food crops on their land, namely corn, sweet potatoes, and cayenne pepper. However, due to the sloping land conditions (not flat), a bench terrace was made on the land. What is planted with food plants is on processed land. Meanwhile, wood is planted on the edge of the land, and elephant grass is planted on the edge of the terrace. Timber plants on the edge of the land are intended to prevent landslides, while grass plants function as reinforcing terraces to prevent soil erosion.

Apart from food, other family needs are housing (house improvement) and the need for input (input) for the business undertaken. In this family, the agricultural land in Gunungsari is planted with sengon laut laut as savings to repair houses or other needs. As it is known, the sea sengon laut plant has a fairly high economic value, in line with the increasing demand for wood (Kartodihardjo, 2010). Under these conditions, the price of sengon laut laut wood is high, so that the sengon laut plant becomes a support for the families to be able to repair their house where they live. For them, sengon laut plants as an alternative source of income, considered quite promising compared to other sources of income. At the beginning of planting, some of the farmers' sengon laut plants were planted intercropping with corn, ginger, or cayenne pepper (TTS), but when the sengon laut plant was 3 years and over, it became an annual plant monoculture (MTT).

Some farming families also raise livestock and has sawmills. Therefore, the types of plants cultivated on their land are an effort to meet the input needs for their business. For the farmers who raise cattle, one of their animal feed needs is obtained from elephant grass planted on the edge of the terrace on their land. Meanwhile, the farmers who have sawmills, their motivation to plant timber plants on their land is to meet the demand for wood raw materials in their sawmill business.

b. Land Area and Non-Agricultural Work

Several informants stated that the land area of the farmers in the Kelampok hamlet was classified as narrow (less than 0.500 hectares), including the land in Gunungsari area. Because of that, they cannot depend on the fulfillment of their family's daily needs on agriculture. This means that his main livelihood is outside agriculture. Meanwhile, agricultural products from their land are seen as a secondary source of income. They consist of the younger generation who have the opportunity to work as construction workers on several residential projects and as laborers in the asbestos, cigarette, convection, soy sauce industry, and several other industries that have developed in the suburbs of Malang and are relatively close to their homes.

Most of their time is devoted to activities outside the agricultural sector, and they do not have enough time to work on their farms. Or agricultural affairs are left to their parents who are over 50 years old. With this limited time, the plant species and cropping patterns were chosen as timber plants, namely sengon laut laut (TTS, MTT). Sea sengon laut plants are planted intercropping when they are less than 3 years old, but after that (over 3 years old) are maintained by monoculture (MTT). This plant does not require much labor and farming costs, as stated by the SPT informant as follows.

"If the wood is delicious, bro, plant it once, you just have to wait, even though the grass is high underneath, it doesn't matter, if after harvesting, plant it again. If you want to plant more seeds, you will be laborers. For basiah (sengon laut laut) the harvest is 5-7 years, fast. Sometimes it's been harvested 4 years, see from the crop, if the soil is often fertilized, it's so fast. If you plant the wood, 
you give the kolonjono the bottom, for animal feed it is good, "(SPT, Kasun Turi).

The statement above shows that for those who have a main job outside of agriculture, the narrow land they own is more appropriate for planting sengon laut laut, because it does not require much labor or costs. That's why these families chose sengon laut plants to cultivate on their land. In addition, the marketing of sengon laut wood is relatively easy, because in Kucur village and in the surrounding villages, sawmills have developed. According to SPT, in Kucur village there are 12 sawmill entrepreneurs. In addition, the price of sengon laut wood is quite good compared to other plants. The findings of this study are different from the results of research (Astuti et al., 2008) which state that timber plants are only cultivated by upper layer farmers (broad). In this research location, timber plantations are cultivated by lower layer farmers and upper layer farmers (area) with relatively different orientations.

c. Support Official and other related
village, Dau sub-district is part of the Metro SubDAS. This sub-watershed is part of the Brantas watershed. Therefore, this area has become the target of a reforestation program from Perhutani, the Forest Service, and Perum Jasa Tirta II. Meanwhile, for the Malang Regency Agriculture Office, the Dau sub-district (including Kucur village) was designated as a fruit development area in Malang Regency.

One of the main forms of support provided by Perhutani, the Forest Service, and Perum Jasa Tirta II is the assistance of sengon laut laut seeds. As stated by the KSD informant as follows:

"... There has been a reforestation program since 1998, farmers have received free seed assistance from the Agriculture Office. In Kelampok Hamlet, most farmers plant timber trees, because the villagers (housewives) also work as factory workers, because they are close to industries such as cigarettes, convection, and soy sauce. The income is considered to be more profitable than agricultural laborers "(ED).

"The growing number of sengon laut or timber plants in Gunungsari was caused by the assistance of a seed program from the village government in collaboration with Jasa Tirta, the Forestry Service and also
Perhutani in 2009-2012. From then on, more and more people were involved in planting sengon laut independently. Sengon laut seeds were obtained from Cak Amin, a seed seller from Turen "(KSD).

The assistance of sengon laut seedlings from outside parties is a stimulant for the farmers to plant timber plants so that the area becomes a conservation area and to avoid land or environmental degradation. This seed assistance has an important meaning for the farmers because, given the existing economic conditions, they do not need to pay for the seeds. Moreover, sengon laut plants are easy to grow without demanding intensive maintenance.

On the other hand, since 2011, in this village a national horticultural development program has been introduced. In Malang district, one of the locations designated by the Department of Agriculture is the Dau sub-district, including Kucur village. Information was obtained from several informants, that from the initial outreach activities in 2010, many farmers in Kucur village cultivated citrus plants, even though they received seed assistance from the government, except for the farmers in Sumberbendo hamlet. Therefore, in the early years of development, the area of the stone tangerine plant was concentrated in the hamlet of Sumberbendo, Kucur village. But over the time, and seeing the success of the farmers planting oranges at the start of the program, some farmers in Gunungsari area began to become interested and switch to citrus plants, moreover they received seed assistance from the government, as said by the KSD informant as follows.

"Earlier this year (2017) citrus seeds were given as many as 5000 seeds. Every year Kucur Village gets seeds and semi-organic fertilizer. Farmers who are willing to take part in the changes are on average who follow farmer groups ".

"Batu 55 citrus seed assistance to farmers as many as 25,000 seeds in 2018. This assistance is given to each household of 100 seeds. Some of the farmers who receive the seed assistance have land in Gunung Sari ".

According to the farmers, Batu 55 tangerine farming does not require attention from farmers, but it is not as intensive as large red chili farming as is done by farmers in Sumberbendo hamlet.

"As for the oranges in addition to holding the housing down, the maintenance is not 
too intense, it is only for the side, maybe only spraying every week. But if the central government does not supply the seeds, it is possible to leave them planted with sugar cane and wood". (SPT).

From the statement above, it is revealed that assistance from outside parties determines the choice of farmers' land management systems. This was chosen because it was considered profitable and did not add to the burden on the farming family, both in terms of costs and labor.

Support or Influence of Other Farmers in the Area of Their Land Planting this sengon laut plant with the help of the relevant agencies will not achieve success without receiving a welcome and support from the farmers themselves. There are roles of several farmer leaders who have contributed to the cultivation of sengon laut laut as stated by the TSM informant as follows.

"Initially, many sengon laut farmers were from Klampok hamlets with guardian farmers namely P. Tasmat, P. Kasidi, P. Daman, P. Sanuri, P. Suwono, and P. Jumari. Meanwhile, in GunungSari, many have started planting sengon laut after the last 10 years (2009) ". (TSM).

From the statement, it shows that several farmers in this hamlet play a role in motivating the surrounding farmers to plant sengon laut laut plants. The motivation to plant sengon laut is also due to see the success of the farmers in neighboring villages in planting sengon laut laut plants as stated by MSM as follows.

"Sengon laut planting is seen from neighboring villages such as Wagir which eventually was followed by farmers in
Kucur Village. Sengon laut plants grew rapidly around $1995 "$. (MSM).

The statement above shows that the farmers planted sengon laut laut because there were experiences of successful farmers from other villages, so they were motivated to imitate and apply sengon laut cultivation to their land. From the description above, it appears that the farmers' choice of agricultural land management strategies in Gunungsari area is not determined by a single factor, but it is the result of the interaction between many internal and external factors of the family.

The strategy for managing agricultural land in Gunungsari area is in line with the actor's approach. However, the actor's approach in question is not individual decision-making in determining action choices solely on rational economic considerations as suggested by Popkin, and ignores socio-economic and ecological environmental factors. But the actor approach or adaptive strategy as proposed by Barlet. Farmers in determining the choice of the land management strategies are based on the internal conditions of their respective farmer families by the social, economic, political (policy), and ecological contexts(Hidayat, 2010; Wiesmann and Hurni,2011). The results of this study are in line with the findings (Hairiah \& Widianto, 1995), namely that the number of choices for agricultural systems (strategies) made by farmers is increasingly complex so that more livelihoods are obtained from agricultural activities.

To see the overall conditions that encourage farmer households to implement land management strategies, the following resume is presented in the form of a matrix (table 5).

Table 5. Matrix that Encourages the Choice of Farmers' Land Management Strategies in the Gunungsari Area, 2019.

\begin{tabular}{lll}
\hline Internal and external factors & $\begin{array}{c}\text { Direction of encouragement } \\
\text { (Support / less support) }\end{array}$ & \multicolumn{1}{c}{$\begin{array}{c}\text { Description of support / } \\
\text { resistance }\end{array}$} \\
\hline Family needs & 1. Fulfillment of daily food needs & $\begin{array}{l}\text { In meeting the daily needs of } \\
\text { agricultural land in Gunungsari, it } \\
\text { will tend to be managed with } \\
\text { seasonal crops of vegetables and } \\
\text { food crops, relying on the yields of } \\
\text { the planting season. }\end{array}$ \\
& & $\begin{array}{ll}\text { 2. Fulfilling needs with a large } \\
\text { allocation of funds, such as house }\end{array}$ \\
repairs, celebrations, and schools & $\begin{array}{l}\text { Gunungsari earn income to meet } \\
\text { their daily food needs, so the } \\
\text { opportunity for the need for a large } \\
\text { fund killing will be more difficult. } \\
\text { The existence of woods (sengon) }\end{array}$ \\
&
\end{tabular}




\section{Fulfill business needs}

cultivated in agricultural land and cattle is saving for households to obtain funds (house repairs, big celebrations, or even schools) so that these needs can be achieved. Land management strategies related to the selection of planting commodities are also carried out based on the household business conditions. Such as planting elephant grass and corn as a provider of animal feed, planting timber for sawmills, and making charcoal or planting sweet potatoes in a farmer's household as a provider of raw materials for making snacks. These commodity choices are also a form of fulfilling the business activities of each farmer's household.

Land Area and Non-Agricultural Narrow land tenure encourages Work farmers to choose the main livelihood activities outside of agriculture

Land tenure in Gunungsari area is not able to meet the daily needs of households so that they increase their livelihood activities outside of agriculture by becoming industrial or construction workers. These activities require a longer time allocation and encourage farming as a side livelihood activity for the household. This insufficient time allocation has encouraged the growth of woodbased agriculture in Gunungsari area as a form of adaptation for livelihood activities.

Support Official and other 1. Reforestation program for the relevant Institution capture of water absorption in the upstream area

The area of Kucur Village, which is the location of Gunungsari Area, is an area of the Sub-Das Metro, part of Das Brantas. Therefore, this area has received the attention of a reforestation program since 1998 by the Government of the Agriculture Service by providing an assistance with timber plant seeds. This continued until between 2009-2012 when the

2. Village areas are included in Government of Perhutani, Jasa the development of "Keprokisasi" fruit trees in the Malang Regency area

Tirta also provided an assistance for wood seedlings, especially sengon laut and jabon, as an effort to reforest the land as a mitigation effort.

The Dau District Agriculture Office, launched the "Keprokisasi" 
program in the Kucur area by providing an assistance in the form of orange seedlings of about 5000 trees, so that this is what encourages the choice of woody plants to increasingly dominate Gunungsari area.

\begin{tabular}{|c|c|}
\hline $\begin{array}{l}\text { Support or Influence of Other } \\
\text { Farmers in the Area of Their } \\
\text { Land }\end{array}$ & $\begin{array}{l}\text { There are examples of success in } \\
\text { wood-based land management } \\
\text { from the surrounding } \\
\text { environment }\end{array}$ \\
\hline
\end{tabular}

The existence of a wood-based land management system in Gunungsari area has been around since 1995 and has grown rapidly around 2009-2012. This land management system is the result of the interaction of each household with the community. The success obtained by the farmer's neighbors encouraged others to adopt the system.

\section{Conclusion}

The conclusions that can be drawn from this research are as follows:

a. Gunungsari is an area of agricultural land in a part of the village of Kucur with a wavy and hilly topography. The dominant land tenure structure in this area is privately owned land with a land area of fewer than 0.500 hectares and tends to be fragmented into land plots with different locations.

b. The land management system is relatively diverse between farmers and between locations of farmers' land and within an area in terms of the cropping system and pattern. There are 5 identified land management systems, namely perennial crop monoculture (MTT), seasonal crop intercropping (TTS), annual crop intercropping (TTT), mixed garden $(K C)$, and seasonal crop monoculture (MTS). Overall, the presence of perennial crops, both timber and fruit trees, remains prominent in farmers' plots and areas. The position of perennial plants in each plot of land is as the main crop, to strengthen the terrace and as a hedge plant.

c. Farmers as important actors in the agricultural land management system. This management system choice is the result of the interaction between internal and external factors of the farming family. The combination of the demands of the family's needs for food, business input, availability of labor and financial capital, area, land conditions and location, easy markets and attractive prices for agricultural products, non-agricultural livelihood activities, support from related external parties, and the success of other farmers creates management strategies. Farmers' choice of land (adaptive strategy) in the form of various forms of land management systems (MTT, TTS, TTT, KC, and MTS) carried out by each farmer household. The choice of farmers inGunungsari area has consequences for the condition of land cover in this area.

Based on the conclusions above, several suggestions can be made as follows.

1) Continuous support from the Village Government and other relevant agencies to the farmers who own land in Gunungsari area to plant annual crops (timber, fruits, plantations) is always provided. The form of support is seed assistance on time and according to need, as well as marketing agricultural products if needed. Thus, the farmers in this area are always motivated to plant good land cover crops, so that the land cover in this area can be maintained in good condition. Because this can further support the sustainability of the springs in this area which is needed for drinking water and bathing garden tours.

2) The dynamics that have developed in the external environment of Kucur village, including the Covid-19 pandemic, are currently interesting for further study. Because this pandemic must have an impact on off-farm job opportunities around Kucur 
village, where some of the villagers have found jobs so far. Directly or indirectly, these conditions can have an impact on the land management in Gunungsari area. Therefore, studies from the perspective of human ecology, rural/agricultural sociology, and agricultural economy are interesting to do.

\section{References}

Agus, F., \& Husen, E. (2005). Tinjauan Umum Multifungsi Pertanian. Prosiding Multifungsi Pertanian, ISBN: 979-, 1-16.

Astuti, Y. A., Dharmawan, A. H., Intan, E., \& Putri, K. (2008). Struktur Nafkah Rumahtangga dan Pengaruhnya terhadap Kondisi Ekosistem Sub DAS Citanduy Hulu, 2(1), 1-30. https://doi.org/10.22500/sodality.v2i1.5895

Gervais., Wiesmann,U. and Hans Hurni (Coeditor)(2011). Research for Sustainable Development: Foundations, Experiences, and Perspectives. NCCR North-South Swiss National Centre of Competence in Research North-South University of Bern Switzerland.

Hairiah, K., \& Widianto, S. D. (1995). Sistem Agroforestri Di Indonesia, 1-19.

Husen, E., Watung, R. L., \& Agus, F. (n.d.). PERSEPSI DAN APRESIASI MASYARAKAT TERHADAP MULTIFUNGSI PERTANIAN: STUDI KASUS DI JAWA BARAT DAN JAWA TENGAH Community' $s$ Perception and Appreciation on the Multifunctionality of Agriculture: Case Study in West and Central Java, 23-45.

Indonesia, P. D. I., \& Tanah, B. P., Adimahardja, A. 2006. Strategi Mempertahankan Multifungsi Pertanian di Indonesia. Indonesian Agricultural Research and Development Journal. 2006 Vol. 25, No.3. Balai Penelitian Tanah, Bogor.

Inman, T, Palte, J.G. 1984. The Development of Java's Rural Upland in Responses to Population Growth. An Introductory Essay in Historitical Perspective. Fakultas Geografi, UGM and Departement of Geography State University of Utrecht.
Kartodihardjo, H. 2010. Hutan Rakyat: Masalah Penelitian Kebijakan dan Kritik Penelitian. Prosiding Seminar Peningkatan Produktivitas Hutan Rakyat untuk Kesejahteraan Masyarakat . Hal. 1-8. Pusat Litbang Peningkatan Produktivitas Hutan. Bogorebijakan, M. P. (2014). H U T A N R A K Y A T :, (October 2010).

Reese., Yin, Robert K.(2009). Studi Kasus: Desain dan Metode. Jakarta:Penerbit Raja Grafindo Persada.

Ruíz, A. A. B. (2015). No 主観的健康感を中心 とした在宅高齢者における健康関連指 標に関する共分散構造分析Title (Vol.3). Retrieved from http://repositorio.unan.edu.ni/2986/1/5624. pdf

Schouten, M., Van der Heide, M., \& Heijman, W. (2009). Resilience of social-ecological systems in european rural areas: theory and prospects. EAAE 113 Seminar, Belgrade, Republic of Serbia, December 9-11, 1-18.

Sudomo, A. (2013). Produktivitas Kacang Tanah (Arachis hypogeae L) di Bawah Tegakan Manglid dalam Sistem Agroforestry. Agrforestri untuk pangan dan lingkungan yang lebih baik. Retrieved from http://www.forda-

mof.org/files/Sistem_Agroforestri_di_Kaw asan_Karst_Kabupaten_Gunungkudul_Unt uk_Pengelolaan_Telaga_Sebagai_Sumber_ Air_Berkelanjutan.pdf

Thieme, S. (2011). Sustaining a Multi-local Life: Possible Theoretical Foundations for Livelihood and Transnational Migration Studies. Research for Sustainable Development (Vol. 6).

Vallance, S, Manurung,R.(2004) Pemenuhan Kebutuhan Hidup Manusia, Dalam Pengetahuan Lingkungan Kuliah 3. Departemen Biologi, ITB Bandung. 